\title{
BERKISAH MELALUI BONEKA TANGAN UNTUK MENINGKATKAN \\ PERKEMBANGAN BAHASA DI RA MUSLIMAT NURUL MUTTAQIN
}

\author{
Mohammad Tsaqibul Fikri ${ }^{1}$ \\ Suwiti $^{2}$ \\ tsaqibul@sunan-giri.ac.id
}

\begin{abstract}
ABSTRAK
Salah satu perkembangan anak usia dini yang harus dikembangkan adalah perkembangan bahasa anak. Bahasa merupakan salah satu media yang digunakan banyak orang untuk bisa berinteraksi dengan sesama dan juga bentuk komunikasi yang paling efektif. Salah satu metode yang bisa digunakan untuk mengembangkan kemampuan bahasa yaitu metode bercerita. Metode bercerita merupakan salah satu pemberian pengalaman belajar bagi anak RA dengan membawakan cerita yang berisi nilai-nilai perjuangan, keagaaman, moral, sosial, dan lain-lain baik secara lisan maupun non lisan.

Kegiatan berkisah dapat menarik fokus anak untuk mendengarkan, maka media boneka tangan dapat digunakan untuk menarik minat anak untuk bisa antusias, senang, dan perhatian dalam mendengarkan guru. Anak lebih mengenal sejarah-sejarah Islam yang ada dijawa agar cerita sejarah pada zaman dahulu tidak punah/hilang begitu saja, maka kami ingin meningkatkan Perkembangan bahasa melalui boneka tangan.

Tujuan dari penelitian ini adalah untuk mengetahui perkembangan bahasa anak sebelum dan sesudah diberikan perlakuan metode bercerita dengan boneka tangan dan menjelaskan pengaruh berkisah melalui boneka tangan dalam meningkatkan perkembangan bahasa anak pada kelompok A. Penelitian ini merupakan jenis penelitian kuantitatif dengan menggunakan pendekatan eksperimen rancangan pretest-posttest test design. Subyek dalam penelitian ini adalah siswa-siswi pada kelompok A di RA Muslimat Nurul Muttaqin Desa Sokogrenjeng Kecamatan Kenduruan Kabupaten Tuban yang berjumlah 28 anak.

Melalui uji statistik Nonparametik dengan menggunakan rumus wilcoxon sign test, maka dari hasil penelitian dapat diperoleh hasil $\mathrm{Z}$ yang dihasilkan adalah $-4,683$ dengam $p$-value (probabilitas) sebesar 0,00 karena nilai p-value (probabilitas) yang di hasilkan kurang dari 0,05. Maka dapat disimpulkan bahwa metode berkisah dengan menggunakan boneka tangan memiliki pengaruh yang signifikan terhadap perkembangan bahasa anak di RA Muslimat Nurul Muttaqin.
\end{abstract}

\section{Kata Kunci: Berkisah, Perkembangan Bahasa, Imajinasi}

\footnotetext{
${ }^{1}$ Penelitian kolaborasi. Dosen Pendidikan Islam Anak Usia Dini IAI Sunan Giri Bojonegoro

${ }^{2}$ Guru RA Muslimat Nurul Muttaqin Tuban
} 


\section{PENDAHULUAN}

Berbagai upaya dilakukan untuk meningkatkan perkembangan bahasa permulaan anak pada TK melalui stimulasi yang tepat dan aman khususnya dalam media pembelajaran. Guru dapat membuat pembelajaran seperti bermain sambil belajar, anak dapat dengan mudah memahami, karena media pembelajaran yang menarik. Pentingnya memberikan stimulasi pada anak usia dini, hal tersebut tercantum dalam Undang-Undang Nomer 20 Tahun 2003 tentang sitem Pendidikan Nasional, pada Pasal 1 butir 14 pendidikan anak usia dini yaitu, "suatu upaya pembinaan yang ditunjukan kepada anak sejak lahir sampai dengan usia enam tahun yang dilakukan melalui pemberian rangsangan pendidikan untuk membantu pertumbuhan dan perkembangan jasmani dan rohani agar anak memiliki kesiapan dalam memasuki pendidikan lebih lanjut". 3

Pendidikan formal seperti TK / RA atau yang setara terdapat 6 bidang pengembangan di dalam Kurikulum Tahun 2013 (K13) yang terdapat dalam:

1. Pengembangan pembiasaan yang mencakup perkembangan nilai-nilai agama dan moral serta sosial, emosional dan kemandirian.

2. Pengembangan kemampuan dasar mencakup perkembangan bahasa, fisik motorik, kognitif dan seni.

Dari kedua bidang pengembangan tersebut tujuannya antara lain; Nilai-nilai agama dan moral di mana isi pembelajaran bertujuan menanamkan norma agama dan pembentukan akhlaq anak didik agar dapat berprilaku sesuai dengan norma yang berlaku di lingkungan tempat tinggalnya. Selain norma agama, perkembangan sosial emosional anak didik senantiasa dibimbing agar siswa dapat mengatur keadaan emosi dan bisa menjalankan kehidupannya sebagai makhluk sosial.

Selain itu, perkembangan bahasa juga diberikan di pendidikan PAUD formal dari kemampuan berbahasa verbal maupun nonverbal, dengan tujuan anak didik mampu memahami dan mengungkapkan pikiran dan perasaan yang ada pada anak didik. Perkembangan fisik anak juga diamati secara berkala dan berkesinambungan baik

\footnotetext{
${ }^{3}$ Risa Mufliharsi, Pemanfaatan busy book pada kosakata anak usia dini di PAUD, (Swadaya PKK,Universitas Indraprasta, 2007), hlm. 147
} 
motorik halusnya ataupun motorik kasarnya, dengan tujuan kesehatan fisik jasmaninya dapat berkembang secara optimal.

Selanjutnya mengamati perkembangan kognitif anak didik, yang berkaitan dengan perkembangan kognitif seperti baca tulis, mengenal angka, sains, konsep mengelompokkan, dan meningkatkan kreativitas. Kelima bidang pengembangan tersebut diberi stimulasi agar perkembangannya optimal sehingga anak akan mendapatkan keterampilan hidupnya.

Setiap anak terlahir imajinasi, maka tidaklah aneh kalu seni termasuk dalam 6 aspek perkembangan anak usia dini. Dia bisa berekspresi dan mengekspresikan diri dalam hal musik, drama, lukisan, kerajinan, tari, maupun dalam aspek bahasa. Ia juga lebih menghargai hasil karya seni. Mengamati perkembangan Bahasa dan Seni tersebut sangat menghubungkan, yaitu dalam aspek kegiatan berkisah

Berkisah adalah media yang yang paling tepat untuk anak-anak dalam menanamkan nilai-nilai positif yang akan bermanfaat di dalam kehidupannya di masa mendatang. Media berkisah ini merupakan salah satu pemberian pengalaman belajar bagi anak TK dengan membawakan cerita kepada anak secara lisan. Dunia anak memang dunia yang indah. Keindahannya ini banyak di dorong oleh cerita-cerita yang telah diceritakan seseorang kepada kita imajinasi kita pun tumbuh dengan baik karenanya.

Pertumbuhan imajinasi ini penting sekali untuk membentuk pemikiran inovatif kelak dikemudian hari. Di dalam hal ini berkisah menempati posisi pertama untuk merubah etika anak-anak, karena sebuah kisah mampu menarik anak-anak untuk menyukai dan memperhatikannya. Mereka akan merekam semua imajinasi dan peristiwa yang ada dalam cerita tersebut. Metode ini juga sangat membantu dalam mempengaruhi psikis peserta didik. Hal tersebut karena di dalam berkisah, peserta didik tidak hanya di pengaruhi pikirannya saja tetapi emosinya juga. Di dalam setiap cerita pasti terdapat unsur ide, pikiran, emosi, dan khayal. Karenanya cerita akan lebih terasa 
mendalam dan mengenal bagi peserta didik. Apalagi jika peserta didik adalah anakanak. anak-anak cenderung lebih suka membayangkan dunia-dunia di luar dirinya. ${ }^{4}$

Pada umumnya anak-anak kita akan senang mendengarkan cerita-cerita yang di sampaikan kepadanya. Seringkali apa yang diceritakan seseorang akan menjadi bagian penting dalam perkembangan kejiwaannya. Banyak materi cerita yang didengarnya semasa kanak-kanak masih terus melekat pada ingatannya dan terbawa ke alam pikiran dewasa, baik itu kesan yang positif ataupun kesan yang negatif. Begitu pentingnya fungsi cerita dalam kehidupan anak, terutama sebagai suri teladan yang memberi warna pada kepribadiannya. Cerita-cerita kepahlawanan, keluhuran budi, percintaan yang indah, sering berdampak positif.

Bercerita dalam perspektif Islam sama halnya dengan berkisah tentang kisahkisah Nabi, tokoh Islam, dan kisah-kisah kebaikan yang dengan kisah tersebut dapat mempertebal iman kita kepada Allah. bercerita sudah ada sejak zaman dahulu, bahkan ketika zaman Rasulullah berdakwah. Bercerita tentang keEsaan Allah pada zaman dakwah Rasulullah kepada kaumnya agar kembali ke jalan kebenaran, dengan cerita atau kisah-kisah yang disampaikan oleh Nabi Muhammad banyak orang-orang Quraish yang rela masuk Islam atas ajakan Nabi. Oleh sebab itu, cerita atau kisah sangat berpengaruh dalam proses manusia menuju kebenaran karena dengan bercerita kisahkisah yang baik seseorang mendapatkan nasehat, pengajaran, hikmah, kebenaran, serta peringatan. Sebagaimana yang telah tercantum dalam Al-Qur'an surat Hud ayat 120 yang berbunyi:

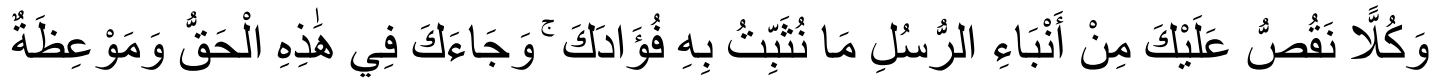 وَذِكْرَى لِلْهُوْْمِنِينَ}

Artinya: Dan semua kisah Rosul-Rosul, Kami Ceritakan Kepadamu (Muhammad), agar dengan kisah itu kami teguhkan hatimu; dan di dalamnya telah

\footnotetext{
${ }^{4}$ Dra. Moeslichatoen R.M.Pd, metode pengajaran di taman kanak-kanak, (Jakarta:2004), hlm. $157-158$
} 
diberikan kepadamu (segala) kebenaran, nasehat dan peringatan bagi orang yang beriman. (QS. Surat Hud, 11: 120) ${ }^{5}$

Serta dalam Al-Qur'an surat Yusuf ayat 111 yang berbunyi:

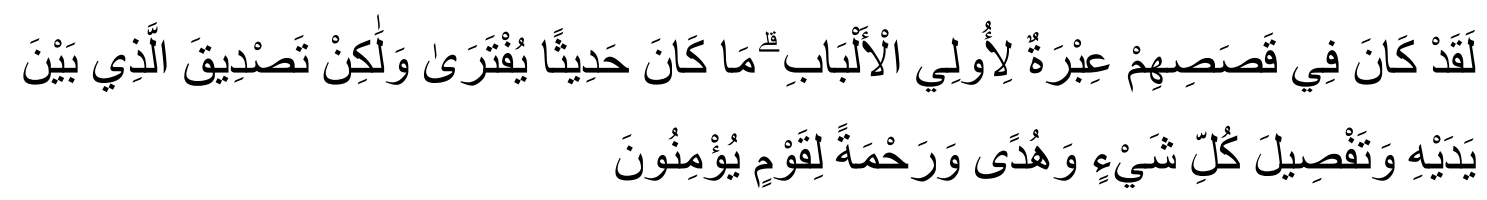

Artinya: Sungguh, pada kisah-kisah mereka itu terdapat pengajaran (hikmah) bagi orang yang mempunyai akal. (Al-Qur'an) itu bukanlah cerita yang di buat-buat, tetapi membenarkan (kitab-kitab) yang sebelumnya, menjelaskan segala sesuatu, dan sebagai petunjuk dan rahmat bagi orangorang yang beriman. (QS. Surat Yusuf , 12: 111) ${ }^{6}$

Dari penjelasan ayat Al-Qur'an di atas, dapat disimpulkan bahwa bercerita mempunyai pengaruh penting selain untuk perkembangan berbicara anak juga bagi terciptanya pembentukan moral dan akhlak setiap manusia. Oleh sebab itu, penting bagi anak-anak untuk diberikan cerita atau kisah-kisah yang baik berupa nasehat, pengajaran, peringatan, serta akhlak terpuji untuk anak-anak agar perkembangan berbicara anak dapat berkembang dengan optimal dan juga perkembangan moral dan akhlak anak dapat berkembang dengan baik dan santun sesuai dengan ajaran agama.

\section{HASIL DAN PEMBAHASAN}

Data yang di paparkan dalam penelitian ini yakni data pengukuran awal (Pretest), kegiatan Pemberian Perlakuan (Treatment), dan data pengukuran akhir (Posttest). Berikut uraian data pelaksanaan selama penelitian berlangsung:

\footnotetext{
${ }^{5}$ QS. Hud Ayat 120. Al-Qur'an dan terjemahannya CV. Karya Insan Indonesia (Karindo) Departemen Agama Republik Indonesia Jakarta No: BD.III/TL.02.1/329/2004.hlm. 345

${ }^{6}$ QS. Yusuf Ayat 111. Al-Qur'an dan terjemahannya CV. Karya Insan Indonesia (Karindo) Departemen Agama Republik Indonesia Jakarta No: BD.III/TL.02.1/329/2004.hlm. 366
} 


\section{Pengukuran awal/sebelum (pretest)}

Pretest merupakan tahapan awal dalam penelitian untuk mengetahui kondisi awal perkembangan bahasa sebelum diberi perlakuan (treatment) yang dilaksanakan pada tanggal 17-19 April 2019. Observasi awal ini dilakukan pada kegiatan inti pembelajaran yaitu kegiatan bercerita dan tanya jawab di depan kelas oleh guru kelas masing-masing. Kegiatan diawali dengan guru mengucapkan salam dan mengondisikan tempat duduk anak. Kemudian guru menyampaikan materi tentang Sunan Asmoro Kondi.

Selanjutnya guru mengajak anak-anak untuk bernyanyi bersama sama dan membaca sholawat. Kegiatan berikutnya guru bercerita tentang Sunan Asmoro Kondi, sedangkan anak-anak menyimak apa yang disampaikan oleh guru. Kegiatan selanjutnya guru memberikan arahan kepada anak-anak untuk menceritakan kembali apa yang sudah disampaikan oleh guru sebelumnya satu per satu anak-anak maju ke depan. Selanjutnya setelah kegiatan bercerita guru juga melakukan tanya jawab kepada anak-anak satu-persatu terkait dengan cerita yang sudah disampaikan.

Pada kegiatan bercerita maupun tanya jawab di kelompok RA A guru melakukan dengan sangat baik. Sedangkan anak-anak masih terlihat malu dan ragu ketika bercerita dan tanya jawab di depan kelas. Bahkan anak-anak mengatakan tidak bisa untuk bercerita di depan kelas. Namun anak-anak tetap maju untuk menilai kondisi awal anak sebelum diberi perlakuan. Penilaian pada kondisi awal ini dengan bantuan guru lainnya untuk menjaga keobjektivitas penilaian. Berikut hasil pretest (observasi awal) tingkat perkembangan bahasa anak kelompok A.

Tabel 1. Hasil Pretest (Observasi Awal)

\begin{tabular}{|c|c|c|c|c|c|c|c|c|c|c|c|c|}
\hline \multirow{3}{*}{ No. } & \multirow{3}{*}{$\begin{array}{l}\text { Inisial } \\
\text { Nama }\end{array}$} & \multicolumn{10}{|c|}{ Aspek yang dicapai } & \multirow{3}{*}{$\begin{array}{l}\text { Skor } \\
\text { Total }\end{array}$} \\
\hline & & \multicolumn{4}{|c|}{$\begin{array}{c}\text { Menceritakan } \\
\text { kembali isi cerita }\end{array}$} & \multirow[t]{2}{*}{ Keterangan } & \multicolumn{4}{|c|}{$\begin{array}{l}\text { Menjawab } \\
\text { pertanyaan }\end{array}$} & \multirow[t]{2}{*}{ Keterangan } & \\
\hline & & 4 & 3 & 2 & 1 & & 4 & 3 & 2 & 1 & & \\
\hline 1. & Adul & & $\sqrt{ }$ & & & $\mathrm{BSH}$ & & & $\sqrt{ }$ & & BB & 5 \\
\hline 2. & Mamat & & & & $\sqrt{ }$ & BB & $\sqrt{ }$ & & & & BSB & 5 \\
\hline 3. & Bayu & & & & $\sqrt{ }$ & $\mathrm{BB}$ & & & $\sqrt{ }$ & & BB & 3 \\
\hline 4. & Rifa & & $\sqrt{ }$ & & & BSH & & $\sqrt{ }$ & & & BSH & 6 \\
\hline
\end{tabular}




\begin{tabular}{|c|c|c|c|c|c|c|c|c|c|c|}
\hline 5. & Khanza & & $\sqrt{ }$ & & $\overline{\mathrm{BB}}$ & & & $\sqrt{ }$ & $\overline{\mathrm{BB}}$ & 3 \\
\hline 6. & Alam & & $\sqrt{ }$ & & BB & & $\sqrt{ }$ & & BB & 4 \\
\hline 7. & Fian & $\sqrt{ }$ & & & $\mathrm{BSH}$ & $\sqrt{ }$ & & & $\mathrm{BSH}$ & 6 \\
\hline 8. & Billy & & & $\sqrt{ }$ & $\overline{\mathrm{BB}}$ & $\sqrt{ }$ & & & $\mathrm{BSH}$ & 4 \\
\hline 9. & Tiara & & & $\sqrt{ }$ & BB & & $\sqrt{ }$ & & BB & 5 \\
\hline 10. & Nara & $\sqrt{ }$ & & & BSH & & $\sqrt{ }$ & & BB & 5 \\
\hline 11 & Geulis & & $\sqrt{ }$ & & $\mathrm{BB}$ & & $\sqrt{ }$ & & BB & 4 \\
\hline 12. & Shinta & & $\sqrt{ }$ & & BB & & & $\sqrt{ }$ & $\overline{B B}$ & 3 \\
\hline 13. & Rara & & & $\sqrt{ }$ & BB & $\sqrt{ }$ & & & BSH & 4 \\
\hline 14. & Putra & & $\sqrt{ }$ & & BB & & & $\sqrt{ }$ & BB & 3 \\
\hline 15. & Wenda & & & $\sqrt{ }$ & BB & & $\sqrt{ }$ & & BB & 3 \\
\hline 16. & Vhinza & & & $\sqrt{ }$ & BB & & & $\sqrt{ }$ & BB & 2 \\
\hline 17. & Gustaf & & $\sqrt{ }$ & & $\mathrm{BB}$ & & $\sqrt{ }$ & & BB & 4 \\
\hline 18. & Aldi & & & $\sqrt{ }$ & BB & & & $\sqrt{ }$ & BB & 2 \\
\hline 19. & Barie & & & $\sqrt{ }$ & $\mathrm{BB}$ & & & $\sqrt{ }$ & BB & 2 \\
\hline 20. & Hima & & & $\sqrt{ }$ & BB & & $\sqrt{ }$ & & BB & 3 \\
\hline 21. & Alvin & & & $\sqrt{ }$ & $\mathrm{BB}$ & & $\sqrt{ }$ & & BB & 3 \\
\hline 22. & Frisca & & & $\sqrt{ }$ & BB & $\sqrt{ }$ & & & BSH & 4 \\
\hline 23. & Sandy & & $\sqrt{ }$ & & $\mathrm{BB}$ & & $\sqrt{ }$ & & BB & 4 \\
\hline 24. & Maya & & & $\sqrt{ }$ & $\mathrm{BB}$ & & & $\sqrt{ }$ & BB & 2 \\
\hline 25. & Wafa & & & $\sqrt{ }$ & $\mathrm{BB}$ & & $\sqrt{ }$ & & BB & 3 \\
\hline 26. & Andika & & & $\sqrt{ }$ & BB & & & $\sqrt{ }$ & BB & 2 \\
\hline 27. & Ridho & & $\sqrt{ }$ & & $\mathrm{BB}$ & & & $\sqrt{ }$ & BB & 3 \\
\hline 28. & Sisil & & & $\sqrt{ }$ & BB & & $\sqrt{ }$ & & BB & 3 \\
\hline & \multicolumn{9}{|c|}{ Jumlah } & 100 \\
\hline & \multicolumn{9}{|c|}{ Rata-rata } & 3,57 \\
\hline
\end{tabular}

\section{Keterangan:}

BB : Belum Berkembang

MB : Mulai Berkembang

BSH : Belum Sesuai Harapan

BSB : Berkembang Sangat Baik

Berdasarkan tabel di atas dapat dijelaskan observasi awal (pretest) pada kelompok RA A memiliki jumlah total 100 dengan rata-rata 3,57. Pada item menceritakan kembali isi cerita yang memperoleh nilai 3 terdapat 4 anak yang 
artinya perkembangan bahasa anak dalam aspek bercerita berkembang sesuai harapan (BSH) dengan memenuhi kriteria penilaian yaitu bercerita dengan runtut dan sesuai dengan isi cerita namun dengan bantuan guru. Sedangkan anak yang memperoleh nilai 2 pada aspek bercerita terdapat 8 anak yang artinya perkembangan bahasa anak dalam aspek bercerita mulai berkembang (MB) dengan memenuhi kriteria penilaian yaitu anak bersedia bercerita namun banyak yang kurang sesuai dengan isi cerita. Sedangkan anak yang memperoleh nilai 1 terdapat 16 anak yang artinya perkembangan bahasa anak pada aspek bercerita belum berkembang (BB) dengan memenuhi kriteria penilaian yaitu anak tidak bersedia menceritakan kembali isi cerita.

Pada aspek menjawab pertanyaan yang memperoleh nilai 4 terdapat 2 anak yang artinya dalam aspek menjawab pertanyaan berkembang dengan sangat baik dengan kriteria penilaian yaitu anak mampu menjawab semua pertanyaan dengan benar tanpa bantuan guru. Sedangkan anak yang memperoleh nilai 3 terdapat 5 anak yang artinya dalam aspek menjawab pertanyaan BSH dengan kriteria penilaian yaitu anak menjawab pertanyaan dengan sedikit bantuan dari guru. Sedangkan anak yang memperoleh nilai 2 terdapat 12 anak yang artinya dalam aspek menjawab pertanyaan $\mathrm{BB}$ dengan kriteria penilaian yaitu apabila anak bersedia menjawab pertanyaan guru tetapi jawabannya kurang tepat. Sedangkan anak yang memperoleh nilai 1 terdapat 9 anak yang artinya dalam menjawab pertanyaan dari guru masih BB dengan kriteria penilaian yaitu anak tidak bersedia menjawab pertanyaan dari guru.

Dari penjelasan di atas, dapat disimpulkan ketika observasi awal (pretest) tanpa menggunakan media boneka tangan pada aspek anak menceritakan kembali isi cerita yang sudah disampaikan oleh guru semua anak masih belum bisa mandiri bercerita di depan kelas tanpa bantuan guru. Anak-anak masih di bantu dengan guru saat di minta untuk menceritakan kembali, serta ada beberapa anak yang lebih banyak berada di belakang asyik bermain dengan temantemannya dan tidak menyimak guru dan temannya saat bercerita. Sedangkan observasi awal (pretest) pada aspek menjawab pertanyaan terkait dengan isi cerita yang sudah di sampaikan oleh guru ada beberapa anak yang sudah 
berkembang dalam menjawab pertanyaan guru dengan benar, anak-anak yang lain juga sudah belum berkembang meskipun masih dengan bantuan guru maupun masih kurang tepat dalam menjawab.

\section{Perlakuan (treatment)}

Perlakuan (treatment) dilakukan pada tanggal 20-23 April 2019, perlakuan yang diberikan kepada anak-anak adalah pembelajaran menggunakan metode bercerita dengan boneka tangan. Adapun proses pemberian perlakuan (treatment) sebagai berikut:

a) Perlakuan (treatment) pertama

Perlakuan pertama diberikan pada tanggal 20 April 2019. Kegiatan pada perlakuan pertama adalah kegiatan bercerita dan tanya jawab yang dilakukan dengan menggunakan media boneka tangan. Tujuan dari pemberian perlakuan ini adalah untuk menarik minat anak dalam memperhatikan dan menyimak guru saat bercerita kemudian membuat anak termotivasi untuk bersedia menceritakan kembali isi cerita yang telah di sampaiakan guru dan menjawab pertanyaan dari guru terkait dengan isi cerita.

Kegiatan diawali dengan guru mengucapkan salam dan mengondisikan tempat duduk anak serta memberikan ice breaking terlebih dahulu. Selanjutnya guru meminta anak-anak mentaati aturan selama kegiatan bercerita berlangsung yaitu untuk tetap duduk tenang, tidak berbicara dan bergurau dengan teman, diam, dan menyimak guru dalam bercerita. setelah anak-anak sudah kondusif, guru melakukan kegiatan bercerita dengan boneka tangan dengan judul cerita "singa dan jerapah". Kemudian kegiatan berikutnya guru memberikan arahan kepada anak-anak satu per satu untuk menceritakan kembali isi cerita yang sudah di sampaikan oleh guru dengan menggunakan boneka tangan di depan kelas.

Setelah kegiatan bercerita di lanjutkan dengan guru melakukan tanya jawab kepada anak-anak terkait dengan isi cerita yang meliputi nama masing-masing tokoh, watak/sifat masing-masing tokoh, tempat kejadian cerita, amanat/pesan dalam isi cerita, dan lain-lain. Pada perlakuan pertama ini guru melakukan 
kegiatan bercerita dan tanya jawab dengan sangat baik. sebagian anak-anak tampak antuasias dan tertarik untuk menyimak cerita yang di sampaikan oleh guru. tetapi saat guru meminta anak-anak untuk menceritakan kembali anak-anak masih malu untuk bercerita di depan teman-temannya, setelah memberikan dorongan dan motivasi terhadap anak-anak ada satu anak yang bersedia bercerita ke depan tetapi masih dengan bantuan guru. Sedangkan pada kegiatan tanya jawab, hanya empat anak yang bersedia menjawab pertanyaan dari guru meskipun masih ada yang dengan bantuan guru. Hal tersebut menunjukkan bahwa perkembangan bahasa anak belum nampak dan BB.

b) Perlakuan (treatment) kedua

Perlakuan kedua diberikan pada tanggal 21 April 2019. Kegiatan pada perlakuan kedua adalah kegiatan bercerita dan tanya jawab yang dilakukan dengan menggunakan media boneka tangan. Tujuan dari pemberian perlakuan ini adalah untuk menarik minat anak dalam memperhatikan dan menyimak guru saat bercerita kemudian membuat anak termotivasi untuk bersedia menceritakan kembali isi cerita yang telah di sampaikan guru dan menjawab pertanyaan dari guru terkait dengan isi cerita.

Kegiatan diawali dengan guru mengucapkan salam dan mengondisikan tempat duduk anak serta memberikan ice breaking terlebih dahulu. Selanjutnya guru meminta anak-anak mentaati aturan selama kegiatan bercerita berlangsung yaitu untuk tetap duduk tenang, tidak berbicara dan bergurau dengan teman, diam, dan menyimak guru dalam bercerita. setelah anak-anak sudah kondusif, guru melakukan kegiatan bercerita dengan boneka tangan dengan judul cerita "Sunan Asmoro Kondi”. Kemudian kegiatan berikutnya guru memberikan arahan kepada anak-anak satu per satu untuk menceritakan kembali isi cerita yang sudah di sampaikan oleh guru dengan menggunakan boneka tangan di depan kelas. Setelah kegiatan bercerita di lanjutkan dengan guru melakukan tanya jawab kepada anakanak terkait dengan isi cerita yang meliputi nama masing-masing tokoh, watak/sifat masing-masing tokoh, tempat kejadian cerita, amanat/pesan dalam isi cerita, dan lain-lain. 
Pada perlakuan kedua ini guru melakukan kegiatan bercerita dan tanya jawab dengan sangat baik. anak-anak sudah mulai banyak yang tampak antusias dan tertarik untuk menyimak cerita yang di sampaikan oleh guru. tetapi pada kegiatan menceritakan kembali sebagian anak-anak masih malu untuk bercerita di depan teman-temannya, setelah memberikan dorongan dan motivasi terhadap anak-anak ada satu anak yang bersedia bercerita ke depan dengan baik tanpa bantuan guru.

Terdapat tiga anak pula yang bersedia bercerita tetapi masih dengan bantuan guru. Sebagian anak-anak bersedia bercerita tetapi tidak lengkap dan tidak sesuai dengan isi cerita, dua anak yang lain tidak bersedia bercerita dan asyik bermain di belakang. Sedangkan pada kegiatan tanya jawab, hanya empat anak yang bersedia menjawab pertanyaan dari guru dengan benar tanpa bantuan guru. Terdapat 5 anak yang bersedia menjawab pertanyaan guru tetapi dengan bantuan guru. Terdapat 5 anak yang lainnya bersedia menjawab pertanyaan guru meskipun jawabanya kurang tepat. Hal tersebut menunjukkan bahwa perkembangan bahasa anak sudah mulai nampak dan BB.

c) Perlakuan (treatment) ketiga

Perlakuan ketiga diberikan pada tanggal 22 April 2019. Kegiatan pada perlakuan ketiga adalah kegiatan bercerita dan tanya jawab yang dilakukan dengan menggunakan media boneka tangan. Tujuan dari pemberian perlakuan ini adalah untuk menarik minat anak dalam memperhatikan dan menyimak guru saat bercerita kemudian membuat anak termotivasi untuk bersedia menceritakan kembali isi cerita yang telah di sampaiakan guru dan menjawab pertanyaan dari guru terkait dengan isi cerita. Kegiatan diawali dengan guru mengucapkan salam dan mengondisikan tempat duduk anak serta memberikan ice breaking terlebih dahulu.

Selanjutnya guru meminta anak-anak mentaati aturan selama kegiatan bercerita berlangsung yaitu untuk tetap duduk tenang, tidak berbicara dan bergurau dengan teman, diam, dan menyimak guru dalam bercerita. setelah anakanak sudah kondusif, guru melakukan kegiatan bercerita dengan boneka tangan dengan judul cerita "Sunan Bonang". Kemudian kegiatan berikutnya guru 
memberikan arahan kepada anakanak satu per satu untuk menceritakan kembali isi cerita yang sudah di sampaikan oleh guru dengan menggunakan boneka tangan di depan kelas. Setelah kegiatan bercerita di lanjutkan dengan guru melakukan tanya jawab kepada anak-anak terkait dengan isi cerita yang meliputi nama masing-masing tokoh, watak/sifat masing-masing tokoh, tempat kejadian cerita, amanat/pesan dalam isi cerita, dan lain-lain.

Pada perlakuan ketiga ini guru melakukan kegiatan bercerita dan tanya jawab dengan sangat baik. sudah banyak anak-anak tampak antuasias dan tertarik untuk menyimak cerita yang di sampaikan oleh guru. pada kegiatan bercerita anak-anak juga sudah banyak bersedia untuk bercerita di depan teman-temannya, meskipun masih terdapat anak-anak yang masih dengan bantuan guru dan masih belum lengkap dan tepat dalam bercerita. Namun ada tiga anak yang bersedia bercerita di depan kelas tanpa bantuan guru.

Sedangkan pada kegiatan tanya jawab, hampir seluruh anak bersedia menjawab pertanyaan dari guru baik itu tanpa bantuan guru, dengan bantuan guru, dan masih kurang benar dalam menjawab. Hal tersebut menunjukkan bahwa perkembangan bahasa anak sudah berkembang dengan sangat baik dan berkembang dengan sesuai harapan.

\section{Observasi akhir (Posttest)}

Observasi akhir (Posttest) merupakan tahapan akhir dalam penelitian untuk mengetahui kondisi akhir percaya diri anak pada kelompok RA A yang dilaksanakan pada 24-26 April 2019. Observasi akhir ini dilakukan sama seperti pretest pada kegiatan inti pembelajaran yaitu kegiatan bercerita dan tanya jawab di depan kelas. Kegiatan diawali dengan guru mengucapkan salam dan mengondisikan tempat duduk anak. Kemudian guru menyampaikan materi tentang bercerita tentang Asmoro kondi dengan menggunakan boneka tangan.

Kegiatan selanjutnya guru memberikan arahan kepada anak untuk menceritakan kembali dengan boneka tangan satu per satu di depan kelas. Setelah itu di lanjutkan dengan kegiatan tanya jawab dengan anak-anak terkait dengan isi 
cerita yang sudah di dengarkan.Berikut hasil posttest tingkat perkembangan bahasa anak kelompok A.

Tabel 2. Hasil Posttest (Observasi Akhir)

\begin{tabular}{|c|c|c|c|c|c|c|c|c|c|c|c|c|}
\hline \multirow{3}{*}{ No. } & \multirow{3}{*}{$\begin{array}{l}\text { Inisial } \\
\text { Nama }\end{array}$} & \multicolumn{10}{|c|}{ Aspek yang dicapai } & \multirow{3}{*}{$\begin{array}{l}\text { Skor } \\
\text { Total }\end{array}$} \\
\hline & & \multicolumn{4}{|c|}{$\begin{array}{c}\text { Menceritakan } \\
\text { kembali isi cerita }\end{array}$} & \multirow[t]{2}{*}{ Keterangan } & \multicolumn{4}{|c|}{$\begin{array}{l}\text { Menjawab } \\
\text { pertanyaan }\end{array}$} & \multirow[t]{2}{*}{ Keterangan } & \\
\hline & & 4 & 3 & 2 & 1 & & 4 & 3 & 2 & 1 & & \\
\hline 1. & Adul & $\sqrt{ }$ & & & & $\overline{B S B}$ & & $\sqrt{ }$ & & & $\mathrm{BSH}$ & 7 \\
\hline 2. & Mamat & $\sqrt{ }$ & & & & BSB & & $\sqrt{ }$ & & & $\mathrm{BSH}$ & 7 \\
\hline 3. & Bayu & $\sqrt{ }$ & & & & BSB & & $\sqrt{ }$ & & & $\mathrm{BSH}$ & 7 \\
\hline 4. & Rifa & $\sqrt{ }$ & & & & BSB & $\sqrt{ }$ & & & & BSB & 8 \\
\hline 5. & Khanza & & $\sqrt{ }$ & & & BSH & $\sqrt{ }$ & & & & BSB & 7 \\
\hline 6. & Alam & $\sqrt{ }$ & & & & BSB & $\sqrt{ }$ & & & & BSB & 8 \\
\hline 7. & Fian & $\sqrt{ }$ & & & & BSB & $\sqrt{ }$ & & & & BSB & 8 \\
\hline 8. & Billy & & & $\sqrt{ }$ & & BB & $\sqrt{ }$ & & & & BSB & 6 \\
\hline 9. & Tiara & & & $\sqrt{ }$ & & BB & $\sqrt{ }$ & & & & BSB & 6 \\
\hline 10. & Nara & $\sqrt{ }$ & & & & BSB & $\sqrt{ }$ & & & & BSB & 8 \\
\hline 11 & Geulis & $\sqrt{ }$ & & & & BSB & $\sqrt{ }$ & & & & BSB & 8 \\
\hline 12. & Shinta & $\sqrt{ }$ & & & & BSB & $\sqrt{ }$ & & & & BSB & 8 \\
\hline 13. & Rara & & & $\sqrt{ }$ & & BB & $\sqrt{ }$ & & & & BSB & 6 \\
\hline 14. & Putra & $\sqrt{ }$ & & & & BSB & $\sqrt{ }$ & & & & BSB & 8 \\
\hline 15. & Wenda & & & $\sqrt{ }$ & & $\mathrm{BB}$ & & $\sqrt{ }$ & & & $\mathrm{BSH}$ & 5 \\
\hline 16. & Vhinza & & & $\sqrt{ }$ & & $\mathrm{BB}$ & $\sqrt{ }$ & & & & BSB & 6 \\
\hline 17. & Gustaf & & $\sqrt{ }$ & & & BSB & $\sqrt{ }$ & & & & BSB & 8 \\
\hline 18. & Aldi & & & $\sqrt{ }$ & & $\mathrm{BB}$ & $\sqrt{ }$ & & & & BSB & 6 \\
\hline 19. & Barie & & $\sqrt{ }$ & & & BSH & $\sqrt{ }$ & & & & BSB & 7 \\
\hline 20. & Hima & & $\sqrt{ }$ & & & BSH & $\sqrt{ }$ & & & & BSB & 7 \\
\hline 21. & Alvin & & $\sqrt{ }$ & & & $\mathrm{BSH}$ & $\sqrt{ }$ & & & & BSB & 7 \\
\hline 22. & Frisca & & $\sqrt{ }$ & & & BSH & $\sqrt{ }$ & & & & BSB & 7 \\
\hline 23. & Sandy & & & & & $\mathrm{BSH}$ & $\sqrt{ }$ & & & & $\mathrm{BSH}$ & 6 \\
\hline 24. & Maya & & & $\sqrt{ }$ & & BB & $\sqrt{ }$ & & & & BSB & 6 \\
\hline 25. & Wafa & & $\sqrt{ }$ & & & $\mathrm{BSH}$ & $\sqrt{ }$ & & & & BSB & 7 \\
\hline 26. & Andika & & $\sqrt{ }$ & & & BSH & $\sqrt{ }$ & & & & BSB & 7 \\
\hline 27. & Ridho & & & $\sqrt{ }$ & & $\mathrm{BB}$ & & $\sqrt{ }$ & & & $\mathrm{BSH}$ & 5 \\
\hline \multirow[t]{3}{*}{28.} & Sisil & & & $\sqrt{ }$ & & $\mathrm{BB}$ & & $\sqrt{ }$ & & & $\mathrm{BSH}$ & 5 \\
\hline & \multicolumn{11}{|c|}{ Jumlah } & 191 \\
\hline & & & & & & Rata-rata & & & & & & 6,82 \\
\hline
\end{tabular}


Berdasarkan tabel di atas dapat dijelaskan observasi akhir (posttest) pada kelompok RA A memiliki jumlah total 191 dengan ratarata 6,82. Pada item menceritakan kembali isi cerita yang memperoleh nilai 4 terdapat 11 anak yang artinya perkembangan bicara anak dalam aspek bercerita dengan memenuhi kriteria penilaian yaitu bercerita dengan runtut dan sesuai dengan isi cerita tanpa bantuan guru. Sedangkan anak yang memperoleh nilai 3 pada aspek bercerita terdapat 8 anak yang artinya perkembangan bahasa anak dalam aspek bercerita dengan memenuhi kriteria penilaian yaitu anak bersedia bercerita dengan runtut dan sesuai dengan isi cerita tetapi masih dengan bantuan guru.

Sedangkan anak yang memperoleh nilai 2 terdapat 9 anak yang artinya perkembangan berbicara anak pada aspek bercerita dengan memenuhi kriteria penilaian yaitu anak bersedia bercerita tetapi kurang lengkap dan sesuai dengan isi cerita. Secara keseluruhan tidak ada anak yang memperoleh nilai satu dikarenakan semua anak bersedia bercerita di depan kelas.

Pada aspek menjawab pertanyaan yang memperoleh nilai 4 terdapat 21 anak yang artinya dalam aspek menjawab pertanyaan berkembang dengan sangat baik dengan kriteria penilaian yaitu anak mampu menjawab semua pertanyaan dengan benar tanpa bantuan guru. Sedangkan anak yang memperoleh nilai 3 terdapat 7 anak yang artinya dalam aspek menjawab pertanyaan belum sesuai harapan dengan kriteria penilaian yaitu anak menjawab pertanyaan dengan sedikit bantuan dari guru. Secara keseluruhan tidak ada anak yang mendapat nilai satu karena pada aspek tanya jawab anak-anak bersedia untuk menjawab pertanyaan dari guru.

Dari penjelasan di atas, dapat disimpulkan ketika observasi akhir (posttest) dengan menggunakan media boneka tangan pada aspek anak menceritakan kembali isi cerita yang sudah disampaikan oleh guru sebagian anak sudah bersedia bercerita dengan runtut dan sesuai tanpa bantuan guru, sebagian lagi bersedia bercerita tetapi masih dengan bantuan guru. Dalam kegiatan bercerita dengan menggunakan boneka tangan sudah banyak anak-anak yang tertarik untuk menyimak dan mendengarkan guru saat bercerita meskipun ada anak yang tidak fokus lagi dan kembali asyik bermain sendiri. 
Sedangkan observasi akhir (posttest) pada aspek menjawab pertanyaan terkait dengan isi cerita yang sudah di sampaikan oleh guru hampir keseluruhan 21 anak dari 28 anak mampu menjawab dengan baik dan benar tanpa bantuan guru, sedangkan yang lain 7 anak bersedia menjawab pertanyaan dari guru tetapi masih dengan bantuan guru.

\section{KESIMPULAN}

Dari hasil pembahasan diatas terdapat keterkaitan antara pengaruh metode bercerita bagi anak usia dini dengan perkembangan bahasa anak, hal ini dikarenakan dengan adanya kegiatan bercerita yang bertujuan supaya anak dapat menyimak dan mendengarkan orang dewasa atau orang lain saat sedang berbicara, anak dapat bertanya jika merasa tidak memahami sesuatu, anak dapat menjawab pertanyaan terkait dengan isi cerita, anak dapat meneladani pesan/amanah yang ada di dalam cerita. Dari apa yang sudah di dengar, dipahami, diperhatikan dari isi cerita diharapkan anak-anak dapat mencontoh atau meneladani sifat baik dari isi cerita dan menjauhkan sifat buruk yang ada di dalam cerita, sehingga dapat terbentuk sikap anak-anak yang berakhlakul karimah. Bercerita dapat juga memfungsikan indra pendengaran anak dengan baik untuk membantu dalam meningkatkan perkembangan bahasa anak dengan menambah perbendaharaan kosakata, kemampuan dalam mengucapkan katakata, dan melatih anak dalam merangkai kalimat sesuai dengan tahapan perkembangannya.

Boneka tangan memiliki manfaat bagi anak diantaranya sebagai sarana untuk memudahkan anak dalam mengingat, memahami serta meningkatkan konsentrasi anak untuk mendengarkan cerita yang di sampaikan. Dengan demikian manfaat bercerita dengan boneka tangan dapat diterapkan pada anak usia dini untuk membantu meningkatkan perkembangan bahasa anak salah satunya yaitu perkembangan berbicara anak. 


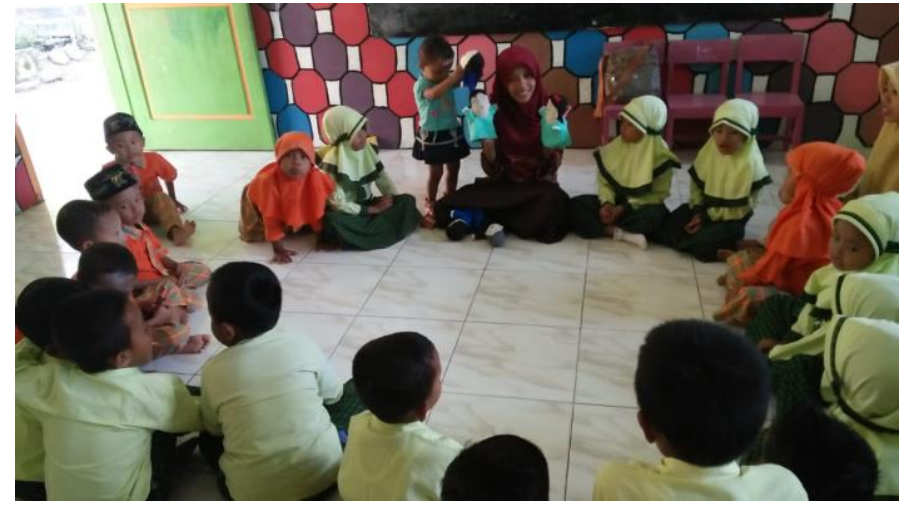

Gb.1. Guru menjelaskan cerita Foto Suwiti (2019)

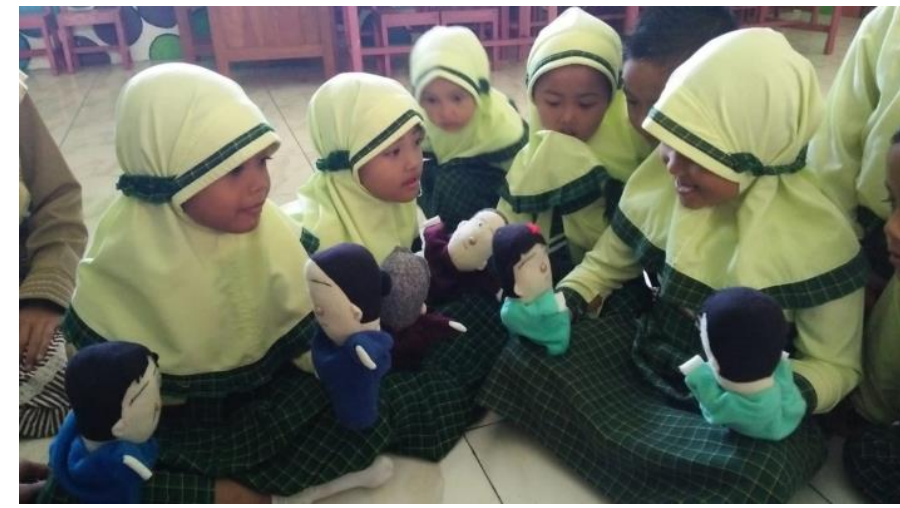

Gb.2. Anak bercerita kembali Foto Suwiti (2019)

\section{DAFTAR PUSTAKA}

Al- Qur'an. 2009. Terjemahan Sirrah Maryam. Pustaka Al-Fatih. Jakarta. Asfandiyar. 2009. Cara Pintar Mendongeng. PT. Mizan Pustaka. Bandung. Daryanto. 2013. Inovasi Pembelajaran Efektif. Yrma Widya. Bandung. Dhieni. 2016. Metode pengembangan bahasa. Universitas Terbuka. Jakarta.

Dhieni, Nurbiana. 2013. metode pengembangan bahasa. Universitas terbuka. Tanggerang.

Dra. Moeslichatoen R.M.Pd. 2004 metode pengajaran di taman kanak-kanak. Jakarta. Gunawan. T. 2005. Mendongeng dengan Boneka. Penerbit Sarana Bobo. Jakarta.

Gunarti, W. 2010. Metode pengembangan perilaku dan kemampuan anak usia dini. Universitas Terbuka. Jakarta.

Latif. 2014. Pendidikan anak usia dini. Kencana prenada media group. Jakarta.

Manna Al-Qattan. 2000. Mabahith fi Ulum al-Qur'an. t.k.t: Maktabah Wahbah. Jakarta. Moeslichatoen. 2004. Metode pengajaran di taman kanak-kanak. Rineka cipta. Jakarta.

Rahmawati. 2005. Relevansi Kandungan Informasi Komponen Arus Kas dan Laba dalam Memprediksi Arus Kas Masa Depan. Jurnal Akuntansi dan Bisnis Jakarta.

Suhartono. 2005. Pengembangan keterampilan bicara anak usia dini. Departemen Pendidikan Nasional. Jakarta.

Suyadi. 2014. Teori pembelajaran anak usia dini dalam kajian neurosains. Rosda. Bandung.

Suyanto. ${ }^{2005}$. Konsep Dasar Anak Usia Dini. Departemen Pendidikan Nasiona. Jakarta Triyanto, Agus. 2007. Pembahasan Tuntas Kompetensi Bahasa Indonesia. Esis. Jakarta. Triyo Supriyanto, M. Samsul Ulum. 2006. Tarbiyah Qur'aniyah. UN Press, Malang. 